\title{
Docência e Orientação no Pós-Graduação da Universidade federal do Rio Grande do Sul: uma trajetória
}

Helga Iracema Landgraf Piccolo*

Falar da minha trajetória no PPG/História da UFRGS envolve algumas variáveis. Antes de mais nada, preciso deixar claro que falar e/ou escrever sobre o que me foi solicitado não é tarefa fácil, porque, ao pensar no que dizer, fui interlocutora de mim mesma, ou seja, eu tive que me interrogar. Entendi dever recuperar minha formação acadêmica - entre 1950 e 1953 - e minha docência na UFRGS a partir de 1959.

Sou bacharel e licenciada em Geografia e História, uma vez que, ao fazer o vestibular, estes dois Cursos não eram, como hoje o são, separados. Além do que, o Bacharelado em três anos letivos

* Professora do PPG em História da UFRGS. Professora Emérita da UFRGS.

Anos 90, Porto Alegre, v. 13, n. 23/24, p.23-27, jan./dez. 2006 
Docência e orientação no Pós-Graduação...

era seguido da Licenciatura, quando as chamadas disciplinas pedagógicas eram ministradas em mais um ano letivo.

É preciso lembrar que, ao cursar o Bacharelado, a então Faculdade de Filosofia não dispunha de prédio próprio, o que determinou a adaptação do horário de nossas aulas à disponibilidade de salas em outros prédios que nem sempre integravam o patrimônio da Universidade, como foi, por exemplo, o prédio do Instituto de Educação, vinculado ao Estado do Rio Grande do Sul. Conseqüentemente, o número de horas/aula a que se assistia era muito inferior ao que hoje é exigido do corpo discente.

O reflexo dessa reduzida carga horária na nossa formação acadêmica foi evidente: conteúdos deixaram de ser vistos e, principalmente, a minha geração não se familiarizou com atividades de pesquisa e com fundamentos teóricos. $\mathrm{Na}$ minha auto-avaliação, essa foi a grande lacuna na minha formação. Eu sou, pois, de uma geração acadêmica que na docência esteve muito próxima de uma História fatual (embora eu não me considere positivista, como já fui rotulada). Os processos históricos e os seus acontecimentos sempre foram privilegiados nos conteúdos que desenvolvi em aula.

O meu Doutorado na Universidade de São Paulo (USP), entre 1969 e 1972, não supriu minhas deficiências teóricometodológicas porque fui dispensada de assistir a cursos e/ou disciplinas. Assim, o aprendizado que fiz, fruto de um esforço pessoal sem nenhuma orientação, acabou sendo fragmentário e, portanto, inconcluso.

Ter concluído o Doutorado possibilitou-me a participação em bancas não só de Mestrado, Doutorado ou Livre-Docência (ao todo foram 81 entre 1976 e 2006), mas também em bancas de Seleção de Professores Universitários (foram 10). Essas bancas, em diversas áreas do conhecimento (História, Filosofia, Política, Educação, Letras), foram significativas como "espaços de experiência", ao propiciarem um amadurecimento profissional e um 
Helga Iracema Landgraf Piccolo

constante aprendizado. Além disso, possibilitaram-me entrar em contato com diversos "modelos" de Pós-Graduação tanto em instituições públicas como privadas de ensino superior (UFRGS, UFSM, UNISC, PUCRS, UCS, UFSC, USP, UFRJ, UFF...) e devo confessar que sempre gostei e continuo gostando de participar de bancas, exatamente porque elas sempre ensinam, por pouco que seja.

\section{Docência e Orientação no PPG em História da UFRGS}

Preliminarmente, devo dizer que a minha experiência em termos de Pós-Graduação iniciou-se fora da UFRGS. Foi no Mestrado em Sociologia Industrial da Pontifícia Universidade Católica do Rio Grande do Sul, onde exerci a docência entre 1974 e 1982. Na UFRGS, a docência começou no Mestrado do Curso de Ciências Sociais em Antropologia, Política e Sociologia, entre 1974 e 1982. Foi também neste Curso de Pós-Graduação que comecei a orientar pós-graduandos, orientação que se estendeu além do período de exercício docente. Foram quatro os meus orientandos na área de Ciência Política, sendo que o último defendeu a sua Dissertação em 1994. Já, então, estava envolvida com a Pós-Graduação em História, curso implantado em 1986, após uma experiência desenvolvida entre 1977 e 1984, com seis Cursos de Especialização (cinco em História do Rio Grande do Sul e um em História da América Latina). O crédito de ter exercido a Coordenação do Curso de Especialização em História do Rio Grande do Sul, no qual orientei dez Trabalhos de Conclusão, levou à minha indicação pela Pró-Reitoria de Pós-Graduação para ser coordenadora da organização e implantação do Curso de Mestrado em História.

A minha aposentadoria, em junho de 1990, não significou o término dos vínculos que eu tinha com o PPG. A minha permanência no Curso estava assegurada pela condição de ser 
Docência e orientação no Pós-Graduação...

Pesquisadora Nível I A do Conselho Nacional de Pesquisa - CNPq (o que fui até fevereiro de 1998). Já, então, havia sido credenciado o Doutorado em História da UFRGS e, mesmo não tendo pedido ao CNPq a renovação da Bolsa de Pesquisa, a minha permanência no PPG foi garantida ao assinar, em fevereiro de 1999, o Termo de Permissão de Uso e Responsabilidade para, conforme Decisão $n^{\circ} 13 / 98$ do CONSUN/UFRGS, prestar serviços voluntários junto ao Departamento de História. E, em outubro de 2005, aceitei exercer atividades junto ao PPG como Professora Colaboradora Convidada. Assim, meus vínculos com o PPG/História subsistem ao serem comemorados os seus 20 anos.

A docência no PPG em História começou com a primeira turma que ingressou no Mestrado e, desta turma, foi a minha primeira orientanda. A mesma experiência tive como docente e orientadora da primeira turma de doutorandos (diga-se de passagem, uma turma de apenas três alunas, hoje conceituadas professoras universitárias). Mas não exerci a docência nem tive orientandos em todas as outras turmas que passaram por nosso PPG ou ainda o estão cursando.

$\mathrm{Na}$ docência, as temáticas por mais pontuais que fossem, sempre se aproximaram de uma História Política. Assim, ao serem institucionalizadas, no PPG, as Linhas de Pesquisa, outra não poderia ser a minha inserção: "Relações de Poder PolíticoInstitucionais". E foi ministrando um Tópico Especial referente a esta Linha, a minha última atuação como docente, no segundo semestre de 2005.

Nesses vinte anos, dez mestrandos concluíram o Curso sob minha orientação, sendo a última dissertação que orientei defendida em 2001. No Doutorado, todos os pós-graduandos que orientei defenderam suas teses, sendo o último em 2004. Se foi um número pequeno de orientandos, há para isto uma explicação com a qual também justifico a minha relativa baixa atividade na docência 
Helga Iracema Landgraf Piccolo

junto ao PPG: sempre preferi dar aula na Graduação. Esta preferência afastou-me, por vezes, do convívio com os pós-graduandos.

Nem sempre temáticas escolhidas por pós-graduandos que pediram minha orientação "fechavam" com os meus interesses como pesquisadora que nunca deixei de ser e ainda sou. Na pesquisa, estive e estou envolvida com questões políticas da História do Rio Grande do Sul no século XIX, do período que abrange "da descolonização à consolidação da República”. Se aceitei alguns orientandos, o foi a pedido da Coordenação do PPG, porque a classificação de um candidato estava na dependência de um professor orientador. Felizmente, nenhum deles me decepcionou. A decepção que tive - se de decepção pode ser falado - ela foi causada pela desistência de quatro mestrandos que não concluíram, por razões diversas, o Curso, embora já estivessem trabalhando no seu projeto.

A minha grande satisfação foi ter podido familiarizar alunos com a historiografia alemã, especialmente a obra Vergangene Zukunft. Zur Semantik geschichtlicher Zeiten de Reinhart Koselleck, evidentemente usada na tradução disponível em espanhol: Futuro pasado. Para una semántica de los tiempos históricos. A receptividade, por parte dos alunos, foi para mim o mais significativo.

Da auto-avaliação da minha trajetória, concluo que ela não foi linear e nem progressiva. Se hoje a minha participação no PPG em História da UFRGS não é mais efetiva, acompanho, no entanto, mesmo que de longe, o seu crescimento e o reconhecimento que conquistou no meio acadêmico. E, como ainda me dedico à pesquisa, espero que o espaço ocupado seja sempre ampliado, devido à excelência do ensino e da pesquisa nele realizados, para que o orgulho que dele tenho, aumente na mesma proporção.

Recebido em 04/11/2006.

Autora convidada. 